\title{
On Borrowed Words and Word Borrowing System in Old Uighur-Chinese Borrowings in Old Uighur
}

\section{Eski Uygurcada Alıntı Sözcükler ve Eski Uygurca-Çince Ödünçleme Sistemi}

\author{
Murat ELMALI* (1)
}

"Corresponding author/Sorumlu yazar: Murat Elmalı (Assoc. Prof.),

Istanbul University, Faculty of Letters,

Department of Linguistics, Istanbul, Turkey.

Shanghai International Studies Universty, Turkish

Culture Studies Center, China.

E-mail: melmali@istanbul.edu.tr

ORCID: 0000-0002-2642-2127

\section{Submitted/Başvuru: 15.06.2019}

Accepted/Kabul: 14.08. 2019

Citation/Atıf: Elmali, M. (2020). On borrowed words and word borrowing system in Old Uighur-Chinese borrowings in Old Uighur. Dilbilim Dergisi - Journal of Linguistics, 34, 57-71. https://doi.org/10.26650/jol.2020.004

\begin{abstract}
Historical linguistics deals with language change. Historical linguistics is sometimes called diachronic linguistics, since historical linguists are concerned with change in language or languages over time. Sound change, analogy and borrowing have traditionally been considered the three most important (most basic) types of linguistic change. The study of loanwords, and of language contact more generally, is a useful way in tracing linguistic change in the past. Because borrowings are very important in Historical Linguistics studies, this study will be about the borrowing of Chinese words in the Old Uigur era writings. This study will try to reveal Chinese borrowings in the Old Uigur era and the reasons for them. Determining the reasons for the borrowing of Chinese words in the Old Uigur era, in which the most voluminous Old Turkish books were written, is the priority of this study. In addition to this, original and new language notes that are summarized from the documents where the borrowings are seen, make this study even more important. In this study, Chinese borrowings in the above-mentioned era will be investigated with historical linguistics methods and the results will be presented to scholars studying Turkish Language or linguistics. In this way, we will contribute something new to Linguistics and Turcology. In this study, we will investigate how Old Uighurs borrowed from foreign languages and whether the borrowings were prestige, reverse prestige or needed borrowings along with other reasons.
\end{abstract}

Keywords: Historical Lingusistics, Old Uigur, Chinese, borrowing, borrowing system, word formation ways

\section{Öz}

Tarihsel dilbilim bir dildeki değişimi inceler. Art zamanlı dilbilim olarak da adlandırılan Tarihsel dilbilim dillerin tarihsel süreç içerisinde yaşadıkları değişime odaklanmaktadır. Ses değişimleri, analoji ve alıntılar Tarihsel dilbilimin üç önemli çalışma alanıdır. Tarihsel dilbiliminin en önemli çalışma alanlarından birisi olan "Alıntı" kavramı dilin tarih içerisinde geçirdiği değişimi takip etmek açısından son derece önemlidir. Alıntıların Tarihsel dilbilim çalışmalarındaki öneminden hareketle hazırlanan bu çalışmada, Eski Uygurca döneminde yazılmış olan eserlerdeki Çince alıntılar incelenmiştir. Bu çalışma ile Eski Uygurca döneminde yapılan Çince alıntı kelimeler ve bu alıntıların neden ve niçin yapıldığı gün 
ışığına çıkarılmaya çalışılacaktır. Eski Türkçe döneminin en hacimli eserlerinin verildiği Eski Uygurca döneminde alıntı kelimelerinin sebeplerinin tespit edilmesi çalışmanın öncelikli amacıdır. Bununla birlikte alıntıların yer aldığı belgelerden çıkarılacak olan orijinal ve yeni dil notları da çalışmayı önemli kılmaktadır. Bu çalışmada bu dönemdeki Çince alıntı kelimeler tarihsel dilbiliminin metotları ile ele alınacak ve çıkan sonuçlar dilbilimi ve Türk Dili üzerine çalışanların ilgisine sunulacaktır. Türkoloji ve Dilbilimine yeni katkılarda bulunulmaya çalışılacaktır. Bu çalışmada Eski Uygurların hangi yollarla yabancı dillerden kelime aldıkları bu kelimeleri prestij, tersine prestij ve ihtiyaçtan dolayı mı aldıkları irdelenecek ve başka sebepler de ele alınacaktır.

Anahtar kelimeler: Tarihsel Dilbilim, Eski Uygurca, Çince, alıntı, alıntılama sistemi, kelime yapma yolları

\section{Introduction}

Historical linguistics deals with language change. It is sometimes called diachronic linguistics, since historical linguists are concerned with change in language or languages over time. The historical linguist may also study changes revealed in the comparison of related languages, often called comparative linguistics. It can be said that languages are related to one another when they descend from (are derived from) a single original language, a common ancestor. In the past, many had thought that the principal domain of historical linguistics was the study of 'how' languages change, believing that answers to the question of 'why' they change were too inaccessible. However, since the 1960s or so, great strides have been made in also understanding 'why' languages change. Today, it can be said that historical linguistics is dedicated to the study of 'how' and 'why' languages change, both to the methods of investigating linguistic change and to the theories designed to explain these changes (Campbell 1999: 4-5). Sound change, analogy and borrowing have traditionally been considered the three most important (most basic) types of lingusitic change (Campbell 1999: 89). The study of loanwords, and of language contact more generally, is a useful way in tracing linguistic change in the past.

The field of historical linguistics had studied the issues related to borrowing by the time of Ferdinand de Saussure's work (1915) in linguistics. To de Saussure, the objects of linguistic study are the internal workings of the linguistic system. The external elements, such as its social use, are outside the scope of this area of linguistic study. The study of borrowing was an example of an external linguistic phenomenon that is important in the historical study of language but is not relevant within a language system: "a loan-word no longer counts as such whenever it is studied within a system; it exists only through its relation with, and opposition to words associated with it..." $(1915,22)$. Edward Sapir's Language (1921) restated the importance of language contact and influence in his chapter on "How Languages Influence One Another.” He noted how Chinese flooded Korean and Japanese with vocabulary and how English borrowed an immense number of words and productive affixes from French, yet in neither case was the borrowing reciprocated. Carefully studying loanwords provides an interesting insight into the history of cultures across the world. In the broadest terms, classical Chinese, Sanskrit, Arabic, Greek and Latin were the five languages that have had an overwhelming significance as carriers of culture. In linguistic terms the way a language reacts to foreign words, by accepting, 
translating, or rejecting them, may shed light on its innate formal tendencies as well as on the psychological reaction of the speakers who use it. In the twenty-eight chapters that comprise Bloomfield's influential Language (1933) three chapters are on the topic of borrowing. In "Cultural Borrowing" he paralleled the individual's early learning of speech forms from those in the household with the later addition of speech forms from the dialects and languages with which the individual and group come into contact. Bloomfield's "Dialect Borrowing" starts with the language learning sequence: home, friends, school, occupation, travel and/or video contact. The speaker learns the language forms appropriate to each, resulting in the speaker's repertoire of variations in forms. The process of acquiring language, including the local, regional, and national or standard forms of speech, was to Bloomfield a part of the overall process of borrowing (Hoffer 2002: 3-4). From de Saussure, loanwords and borrowings studies are important fields of historical linguistics. Many historical linguists use linguistic data from the borrowing studies to understand languages.

To identify loanwords and to distinguish them from inherited vocabulary, it is necessary to apply the comparative linguistic method. Irregular sound correspondences and morphological traits, and a continuous distribution across linguistic boundaries are indicative of borrowing. The possibility of semantic analysis and the presence of cognates in related languages may confirm the identity of the donor language. The identification of loanwords suffers from a few drawbacks, however. Some sounds have not changed for centuries or even millennia, preventing the distinction between loans and inherited words. Or loanwords may have become integrated in the phoneme inventory of the recipient language, giving the impression of regular sound correspondences. But even if loans can be recognized as such, the donor language cannot always be traced. Finally, it must be said that the study of loanwords attains the best results when it is based on well-annotated data, with detailed semantic description and a list of regular sound correspondences and adequate classification at hand (Ricquer 2018).

Borrowing words that pass from one language to another, and have a place for themselves in the vocabulary of the receiver language, are called "borrowed words". Generally, the concept of borrowing is seen in bilingual environments and it is a word that is taken from another language, which was not a part of the vocabulary of the receiver language, and adapts to the vocabulary of the receiver language. It is not possible to classify borrowings as only wordbased. Phonemes, phonological rules, morphemes, syntactic principles, semantic relations, discourse varieties and more could pass from one language to another (Campbell 1999: 57). However, the most common result of the language interactions is that the languages that interact are partly or completely changed. Typically, but not always, one of the languages in the interaction process is at least partly influential on the other language(s) and the most common type of this influence is borrowing (Thomason 2001: 10; Salan 2012: 53).

Every person and society has learned something from someone else or from a different, relative or neighboring society that has experienced varied learning paths and that lives in a 
different historic and geographic environment. Hence, they have borrowed from other people's languages and adapt what they have learned to their own language. Borrowings, which are based on this, are called "knowledge borrowings". Besides these borrowings, which are the results of knowledge acquisition, it may be seen that societies and people also borrowed from another societies and people without learning something or acquiring knowledge. In places and times where more than one society lived in political and geographical unity, we can see borrowings between the representatives of occupied or ruled peoples, lower language, (substratum language) and the representatives of occupants or rulers, upper language (superstratum / dominant language). In these borrowings (Jeffers 1982: 142), generally, it is not about learning or knowledge: rather, it is about political and financial supremacy, rulerruled relationship, emulation and the desire to use trendy language. Borrowings as such are called "prestige (intimate) borrowings" (Karağaç 2008: 151-152). It is not really possible to link substratum and superstratum languages only with ruler-ruled relationships at the present time. It is still a matter of debate whether the substratum-superstratum relationship boundaries have expanded. Today, this relationship is mostly related to financial and cultural supremacy.

According to linguistic research, no language is superior to another one. In that case, borrowing, which means word exchange between languages, is not the work of an inferior language to develop. There is a development at stake but that is about the financial, political, cultural superiorities of the superstratum society, rather than about linguistic needs. However, describing the direction of borrowing as coming from a society that is developed in one way to another society that is relatively underdeveloped in that aspect would hardly be the truth. Therefore, we should note that even though the borrowing direction could be from the language of a society that is financially, politically, culturally developed, to the language of a society emulating it, it could also be vice versa. In fact, there are lots of words that illustrate this. For instance, the word "hamaka" which Cristopher Columbus saw in Haiti, which is an American Indian word and meant "swing bed", spread all around the world and was originally used as "hamaca" in Spanish, "hamac" in French, "hängematte" in German and "hamak" in Turkish (Aksan 2009: 137; Paylan 2015: 125).

While substratum languages could only lend knowledge borrowings to superstratum languages, superstratum languages could lend both knowledge and prestige borrowings to substratum languages (Bloomfield 1933: 461-463). As knowledge borrowings, that is to say "culture-related borrowings", could show us "what one nation teaches to another one" (Bloomfield 1933: 456) and "borrowings are substantially from a superstratum language to a substratum language" (Bloomfield 1933: 461), prestige borrowings have nothing to do with the world of knowledge and learning and necessities of the receiver language (Jeffers-Lehiste 1982: 150; Bloomfield 1933: 461, 462, 471). These kinds of borrowings are the results of the receiver language speaker's desire to fulfil their expectations, hunger and psychological needs such as seeming to be knowledgeable, a feeling of belonging to a 
social group, drawing attention, and at least proving their own existence by differentiating in language use (Karaagaç 2008: 152).

Prestige borrowings such as Ar. şems "sun"> Tur. şems "sun"; Ar. kamer "moon"> Tur. kamer "moon"; Pers. horşid "sun"> Tur. hurşit "sun"; Pers. mah/meh "moon"> Tur. mah "moon" do not bring any new information to Turkish and they disappeared from our vocabulary in the last century when there was nothing to emulate in the Arabic and Persian world for Turkish people. But, knowledge borrowings such as Ar. şemsiye "sunshade" > Tur. şemsiye "umbrella"; Ar. kameriyye "bower" > Tur. kameriye "bower" have become new units of the vocabulary as they bring new information into Turkish (Karaağaç 2008: 152).

Since throughout history and for many centuries Turks were the rulers over spacious lands, the only source of prestige borrowings for the Turkish language was religion. First Buddhism and Manichaeism, then Islam led to many prestige borrowings alongside knowledge borrowings for Turkish. Many words that were borrowed from Buddhism and Manichaeism disappeared when these religions lost their prestige in the eyes of Turks. Because Turks learned Islam through Persian, most of the prestige borrowings in the language are Arabic and Persiansourced (Karaağaç 2008: 153).

There are two kinds of borrowing sources. We could divide borrowings into two, namely internal borrowings which are made from relative accents, and external borrowings which are made from the languages of neighboring nations. It is especially hard to determine internal borrowings, made from accents, because "It is not possible to make a distinction between the language and accent boundaries.” (Bloomfield 1933: 444; Karaağaç 2008: 154)

On the other hand, the borrowing process is bound to the rule of "expressing many things with minimum effort" because creating new words or new word groups that correspond to something, is actually harder than borrowing them. The general reasons why foreign items enter a language are as follows: fundamental changes in social life, changes in the aspect of religion and civilization, translation activities, alphabet changes, deficiency, lack of linguistic consciousness, moving around the world a lot, lack of derivation tools in the language, scientific and technological innovations, the desire to be admired (Durmuş 2004: 2).

Japanese researcher Toshio Ishiwata lists the situations where foreign words are needed as follows: expression of new objects, expression of new ideas, expressing the differences between existing objects by current and different ones, technical words, influence of globalization, expressions that soften the meaning, expressions related to the structure composition of a language (Ishiwata, 2001: 83; Ishihara 2005: 8).

The term "borrowed word" is used for words that enter into a language from a foreign language. A great number of foreign words temporarily entered the Turkish language in the earlier stages. Words that do not have a place in Turkish cannot be considered as borrowings, they are just "foreign words". These foreign words are often seen in the speeches of people with higher education or people who got education through a foreign language. Foreign words, 
mostly standing for "technical terms", are usually used in fields like texts translated from a foreign language, introduction of new concepts and objects and international meetings. A foreign word we temporarily use starts to become a Turkish word when it comes out of its specialization area and goes public. The stages of a word becoming Turkish could be determined through various aspects such as pronunciation and accents, and morphological and semantic alterations. There are only a few words that have never undergone any change and which are completely preserved in their original form (Ishihara 2005: 1).

The words below are considered to be borrowed words:
a. A foreign word that is the only one for the expression.
b. Foreign rooted word + foreign rooted affix: e.g. yaban+î "wild", ahenk+târ "harmonic"
c. Foreign rooted word + Turkish affix (derived word): e.g. limon+cu "lemon dealer", hak + sız+lik "injustice".
d. Foreign rooted word + Turkish word (compound word): e.g. portakal suyu "orange juice", insanoğlu "human being".
e. Foreign rooted word + foreign rooted word: e.g. spor toto "football pools", tuvalet kâğıdı "toilet paper" (Ishihara 2005: 3).

It is well known that the progression of a language depends on the speakers and their ability to produce. The only way for a society to break out of being learners and receivers, and standing against foreign factors, is rising to a position of becoming givers and instructors. Societies with much to give always teach something new to people with lower knowledge. Learners might feel better for a while by hybridizing and translating these new words but even if we shape the knowledge with our national culture and civilization, history will always show us the real origin of the knowledge (Karaağaç 2008: 162-163).

\section{Chinese Borrowings in Old Uighur}

Our study will be about Chinese borrowings in Old Uighur texts and the process of this borrowing. First, the borrowings in these texts will be determined. Then, we will determine the way (namely, through which languages) these words entered Old Uighur and we will try to draw a conclusion about language relationships. Third, we will determine the reasons for these borrowings and try to analyze the language structure of the era. With the outcomes, we will try to conclude the reflex of the Turkish language against borrowings, which has been an ongoing progress since the $6^{\text {th }}$ century.

The aim of this study is to reveal the borrowing system used in Old Uighur. As Old Turkish researchers know, Turkish developed with many foreign words and a great number of foreignsourced words were used in the written works of that time. Determining which of these were borrowings or not is a study topic on its own. In this study, alongside determining the words, we will also try to reveal how and why these words gained a place in the language.

With the knowledge we have today, it does not seem possible for us to decide whether Old Uighurs were bilingual or not. It also appears not to be possible to determine whether 
people who wrote texts and who contributed to the borrowing process, were good at multiple languages or were in a bilingual environment at that time. Determining the ways in which Old Uighur words were borrowed, that is to say the direction of the them, will enlighten us on this topic. To achieve this, historical and comparative linguistics methods will be used. Two of the most important subfields of historical linguistics, the comparative method and the linguistic reconstruction method, will be used to determine both internal and cross linguistic words and structures, and they will be investigated under the topics of "phonological leads", "morphological complexity", "leads from cognate structures", "geographical and ecological leads", "semantic values" and after that, we will attempt to conclude how and why these borrowings were made.

"Chinese Borrowings in Old Uighur", which was a part of the study we conducted for this research, will be our focus, and the question "why does a language borrow something from another language?" will addressed through Chinese borrowings in Old Uighur.

The first important and comprehensive study on Chinese borrowings in Old Uighur is Csongor's 1952 and 1954 published works that contain some new information (1952: $73-121$; 1954: 251-257) and the second one is Shogaito's work (1986: 124-156). Shogaito investigated approximately 500 words and he came up with the reconstructed old Chinese forms and their forms in Uighur texts. In addition, Mehmet Ölmez's Chinese borrowings in Uigur Xuanzang Biography is an another important study (1995: 109-143). For further studies, see also Ölmez 1995. Şaban Doğan's “On Intimate Borrowings in Old Uighur Turkish Translations Text" is another study on borrowings in Old Uighur. (2009). The latest study on Chinese words is Hacer Tokyürek's "Classification of Chinese Words in The Xuanzang Biography" (Tokyürek 2018).

"Actually, these words were not borrowings with real meaning such as hua 'flower', kay 'street' and those elements are seen once or at most a few times in Uighur texts" (Csongor 1952: 75-76; Ölmez 1995: 110).

This borrowing explanation of Csongor makes us rethink the aspect of Old Uighur. At the beginning of the paper, borrowing is explained using its common meaning: "a word passes from one language to another and has a place for itself in the vocabulary", "words that are originally not a part of the vocabulary, taken from another language, fit into target language vocabulary." To determine which word is a borrowed word, within the framework of this definition, it is necessary to investigate the general position of the word, in other words its position in both written and spoken language. As it is not possible to track down Old Uighur in the aspect of speaking, there is only one possible way left to determine borrowed words, namely, the frequency of the words and whether they are used in most of the written works that come from the Old Uighur era to the modern day or not. With the framework around this idea we have prepared a sample list of words that we could consider to be Chinese borrowings in Old Uighur: 
bahşı: < Chin. 博士 bó shì. a wide read scholar; a professor; a doctor of the academy of learning. Also master-tradesman $\left(\mathrm{G}^{1} .9372\right)$.

ban $<$ Chin. 版 băn. a board; a plank; a wooden tablet inscribed with administrative regulations; a block for printing (G. $8589 \rightarrow 8588)$.

burhan $<$ Chin. 佛 fo. + Tur. han Buddha $(\sim$ Skr. buddha $)$

bursay < Sogd. pwrsng(') < Chin. 佛僧 fo sēng. religious community (G. 3589, 9617).

buşı < Chin. 布施 bù shì. donation, alms, handout (G. 9479, 9934). buşıçı < Chin. pu-ş̃ $\tilde{+}+$

Tur. $+c ̧ I$. someone who collects alms. buşılıg $<$ Chin. $p u-s ̧ \tilde{\imath}+$ Tur. $+l X g$. someone who needs alms (Elmalı 2016: 290). buşıçı koltguçı beggar (Şen 2002: 79).

but $<$ Chin. 佛 fó < Skr. buddha. Buddha bwt (G. 3589; Gharib: $115 \mathrm{~b}_{2929}$ ). Buddha.

çı < Chin. 尺 chi. linear measure; a foot, of varying size at various times (G. 1992).

çın $<$ Chin. 真 zhèn. real; true; genuine (G. 589).

çınju < Chin. 畺如 zhēnrú. irrelevant real essence, irrelevance (G. 589, 5668).

çi < Chin. 執 zhi. to hold; to grasp; to seize. to attend; to manage (G. 1795).

çü̈ (silktür-) < Chin. 钟 zhōng. a bell without a clapper. a clock (G. 2893). çü̈ silk-: ÇWY'K SYLK-. corresponds with Chinese zhōng gu (G. 2893, 6241) and mean "ringing a bell or playing a drum" (Röhrborn 1991: 227). çüy silktür- "to make somebody play a bell" (Elmal1 2016: 330). hua $<$ Chin. 華 huá. the blooming of plants, flower; flowery (G. 5005).

labay < Chin. 螺貝 luó bèi. a pipe made from horn, beam; a wind instrument (G. 7289, 8793). lẻm $<$ Chin. 梁 liáng. girder; a level bridge (said to have been originally a dike or bank left by water drying up. a handle to a kettle. a beam, a ridge (G. 7021).

liken $<$ Chin. 利劍 lì jiàn. sharp sword (Soothill-Hodous 1975: 230b).

luu < Chin. 龍 lóng. dragon (Soothill-Hodous 1975: 454b).

ka $<$ Chin. 家 jiā. the family; home; house-hold; relatives. people. a class; a side; a party; a school (G. 1139).

kay $<$ Chin. 街 jiē street (Soothill-Hodous 1975: 390a).

koykiu < Chin. 箜篌 kōng hóu. an instrument; harp (G. 6595, 4015).

kunçuy < Chin. 公主 gōng zhǔ. princess, queen, daughter of the emperor; woman; wife (G. 6568, 2526).

kün < Chin. 䦭 kǔn. a threshold. door leading to women's apartments $\leftrightarrow$ küün (G. 6550). mekke < Chin. 墨 mò. black; ink. (Ölmez 1994: 141; G. 8022; Clauson 1972: 766a). mekkeh "ink; a kind of ink that is brought from China. Turkish writing are written with these." (DLT III: 424; Sertkaya 1978: 573).

pi < Chin. 碑 bei. a large stone tablet; tombstone (G. 8764). pi taş (bi taş) "large stone plate, tombstone"

pra < Chin. 幡 fan. A banner; pennant; a strip of silk with characters embroidered on it (G. 3385); kuşatarė canopy, sail.

say < Chin. 僧 sēng. < Skr. sangha. community, society; a buddhist priest; the buddhist temple (G. 9617).

say < Chin. 藏 zang. to hide; to conceal; to put away; to be in retirement. to hoard; to store up (G. 11601) [倉 cāng].

savşey < Chin. 小乘 xiăochéng, Skr. hīnayāna, small, Hīnayāna sect (G. 4294, 770).

sin $<$ Chin. 蒋 qin. the back section of an ancestral temple (G. 2091).

$\sin <$ Chin. 辛 xinn. one of the five flavours; acrid; bitter. grievous; toilsome (G. 4564). 
sü/süö < Chin. 序 $x u$. east and west; in order; series; precedence. a preface (G. 4771). şık $<$ Chin. 石 shi. a liquid measure; a dry measure; used in the assessment of salaries; measure of grain (G. 9964).

şim $<$ Chin. 壬 rén. concept of time; the ninth of ten heavenly Stems. great. artful. (G. 5610). taişen / tayşing < Chin. 大乘 dà chéng. great yāna, vehicle, Mahāyāna sect; < Chin. 大乘 ta sheng. big car (Skr. mahaāyāna) one of the three biggest sects of Buddhism (G. 10470, 770). taluy < Chin. 大流 da liu. sea, ocean (G. 10470,7248). tayy < Chin. 帶 dài. belt, sash (Soothill-Hodous: 349a). ten $<$ Chin. 等 děng. equal, even; single sort, sort (Soothill-Hodous 1975: 384b).

tètsi < Chin. 弟子 dì zĭ. student, disciple, monk, follower of the master (G. 10950, 12317). toyın $<$ Chin. 道人 dào rén. Buddhist priest, priest, monk that controls his mind and himself through a physical process ( Skr. bhikșu); $\leftrightarrow$ toyun (G. 10780, 5624).

tsi $<$ Chin. 則 $z e$. a pattern; rule. (G. 11652).

tsuy $<$ Chin. 罪 zui. A crime ; an offence; wrong. punishment (G. 11910), tsuylug $<$ Chin. $z u \grave{\imath}+$ Tur. + lxg. Sinner. (Tekin 1976: 483b).

tog / tug / tuug $<$ Chin. 幢 chuáng. a curtain for a carriage. a streamer; a pennant. an hexagonal or octagonal pillar of stone used to take place of a collection of banners hung up in temples in token of thanksgiving (G. 2786).

tuo $<$ Chin. 多 duo. many; much. (G. 11302).

ujik: < Chin. 字 zi. a written character; a word (G. 12324). < ujiklig $<$ Chin. $z i+$ Tur. $+l X g$ "letter, syllabic" (Elmal1 2016: 302).

yan < Chin. 樣 / 样 yang. a pattern; a sample; a kind; a sort; a style (G. 12854).

yüy $<$ Chin. 獲 jue. a large ape found in western China, said to be six feet high and to walk like a man (G. 3244).

This is a sample list. Of course, borrowings in Old Uighur do not consist solely of these words.

Words having low frequency of occurrence like those below could hardly be evaluated as borrowings:

çüen küh < Chin. 顓頊 zhuan $x u$. name of a Khan. (Aydemir 2013: $307_{435}$ ).

çoy-san (tuglar+nı) $<$ Chin. 幢傘 chuang san. chuang 幢 “banner” san 傘 “umbrella; parasol" (Aydemir 2013: 320 ${ }_{573}$ ).

čai < Chin. 齋 zhai 'to abstain from, especially from a meat diet, as Buddhist priests do; fasting (Aydemir 2013: $324_{607}$; G. 234).

kam čah < Chin. 閔澤 kan ze. name of a place (Aydemir 2013: $338_{724-725}$ ).

It is questionable to evaluate the words below as borrowings:

çı $<$ Chin. 尺 chi measure of length.

yüy $<$ Chin. 獲 jue. a kind of monkey.

şlk $<$ Chin. 石 shi. measure of grain.

şim $<$ Chin. 壬 rén. concept of time.

çi $<$ Chin. 執 $z h i$, concept of time.

It is quite hard to draw boundaries for borrowings. However, the words we have listed above could clearly be determined as borrowings. 


\section{Word Borrowing System in Old Uighur}

The stage which comes after the determination process of the borrowings is that of finding out the reason for borrowing. There are three reasons stated for borrowing in historical linguistics studies: Need, prestige and the opposite of prestige.

A language usually borrows a word from another language because of need or prestige/ emulation. Speakers of a language need a new term when they acquire a new knowledge, object or concept from an another language. A foreign noun is often adopted with a new term. The borrowing of automobile by many languages is a good example of this. (Russian avtomobil, Finnish aotu, Swedish bil (last syllable is borrowed)). Another example for this is Turkish kahve which is borrowed by many languages. (English coffee, Russian kofe, Finnish kahvi, Japanese kohii). Arabic tabaq is an interesting example. (English tobacco, Finnish tupakka, Indonesian tembakau, Japanese tabako). Another motive for borrowing is prestige/emulation. For many reasons some languages are considered to be more prestigious and they are usually emulated. These borrowings are made without any requirement and for that they are known as emulation/prestige borrowings and they carry a sense of luxury. Although there are words for 'pig flesh/pig meat' and 'cow flesh/cow meat' in English, the words pork (French porc) and beef (French boeuf) are still borrowed. The Norman French hegemony on England at the time of the borrowings was the reason for this. French had a higher social status and was considered to be a more prestigious language (Campbell 1999: 59).

Another borrowing type is the opposite of prestige even though this is seen less. The process of adapting a foreign word is considered to be an inferiority and lowness and has a negative perspective in the eyes of speakers. (French hâbler "self-praise; blether < Spanish hablar "talking"; Finnish koni "old horse" < Russian kon "horse" (Campbell 1999: 60), Turkish kıro "person without good manners" < Kurdish kuro "young man", Turkish entel "person who wants to seem wise" < French intellectuel "intellectual' person who has an idea).

Borrowings based on learning are called knowledge borrowings and are made because of need. A society which encountered a new knowledge, object or concept would borrow words from other languages. This knowledge, object or concept not being a part of their own language, and the receiver language not being capable of coming up with a new word would have to make an urgent decision because of the economy in language. Borrowings made under these circumstances are qualified as need borrowings. Borrowings based not on knowledge and learning but on political and financial supremacy, ruler-ruled relationship, emulation and the desire to use a new trendy word are prestige borrowings. The opposite of prestige borrowings occurs in order to humiliate the source language and the word is given a humiliating meaning as much as possible.

In this study borrowings made in the Old Uighur era are evaluated according to the three reasons mentioned above and clues are looked for in order to discern the borrowing process in Old Uighur. 
We could summarize the method we will use in this study with the word burhan, which is the most used word then and refers to Buddha. We asked ourselves the question: Is the use of this word an example of borrowing? Does this word have a place in the language and was it known and used by people like the word "peygamber" (prophet)? What is the scope of this word? Does this word only refer to Buddha Siddharta Goatama or does it have a general meaning that refers to "prophets/gods that represent all the Buddhas in Buddhism". Why is it mostly used with the word "tengri"? The word "burhan" is a semi-borrowed word that consists of Chin. fo+Tur. han. Why did the writers then derive and use "han" with "Chin. fo" instead of just using "han"? Why didn't they use "Chin. fo" alone? Is there a word that could have replaced this word in Turkish at that time ? Is this word a semantic borrowing or a morphological borrowing? Why was "Chin. fo" borrowed? Was Chinese a more prestigious language or was this an example of morpheme use for a complete need?

The examples we selected, from the Chinese borrowings list we provided above, with the direction of the questions, will give us an idea about the borrowing system:

bahşı: < Chin. 博士 bó shi. "teacher, master".

If evaluated in frequency it is understood that word bahşı is an example of borrowing. It is possible to see this word in almost every Old Uighur writing. Because of its frequency it could be said that bahşı has its place in the language. It is used in its meaning of a "high level academician; a wise person" (G. 9372) in Chinese and the prominent meaning is a "person who has knowledge and controls it". The meaning originated from the word for "teacher, instructor" and had a wide use, the word being used in this conceptual field in Old Uighur. It could be seen that the word is borrowed from another language instead of Chinese if the phonological leads are evaluated. < Toh. A poyşi "all knowing, Buddha (Adams 2013: 434). The borrowed word açari is used with Turkish kang and a reduplication is made. With all these, it is possible to think that it is hard to know whether a word could be derived in replacement for bahşı in Old Uighur or not, from the verbs boşgur-, biltür- and from the suffixes - $g A n$ or - $g U c ̧ I$. Besides that, it seems hard to know whether boşgurguçı, biltürgüçi or another alternative word could correspond to the conceptual field of "master" first hand, in the context of religion, academy, education and others, or not. It might be thought that the word was accepted in the Old Uighur language and because of its large conceptual field it could have fulfilled a need then, on the basis of the language rule "expressing many things with minimum effort".

ban < Chin. 版 băn. board, writing tablet, tabula.

This word is mentioned in Xuanzang, Daśakarmapathaavadānamālā, Altun Yaruk. It is a borrowed word, used with the meaning "writing tablet, tabula, print, paper, record, version, copy, hand printing" in Chinese. The word is used in this conceptual field in Old Uighur. The word ban, which is borrowed from Chinese with its morphological and semantic structure, is assimilated to Turkish phonology. The second word ban, from the reduplication yazı ban that comes from the noun phrase yazı ban ıgaç, is a Chinese phrase that is synonymous with yazı 
“flat”. This expression looks like [435a27] 版 in the Chinese text. The Chinese word 版 băn was passed to Mongolian through Tibetan, and thereby to Tuvan. The verb parla- "to print, to publish" in Tuvan originated from this word (Ölmez 2007: 238). Structure .....yazı ban lgaç urup..... in Altun Yaruk makes us think of two different reduplications. If we evaluate this by its meaning of "being flat", it forms a reduplication with yazı. If we evaluate it by the meaning of "board", it forms a reduplication with $\operatorname{lgaç~(Çetin~2012:~} 138_{440}$ ). Both of these possible reduplication structures point at the effort made in the Old Uighur language to try and find a replacement for this word. Thus, this makes us think that the word was borrowed to fulfil a need at that time given that there was a tendency to replace words with Turkish alternative structures. This example reminds us of the printır (printer)-yazıcı relationship in Turkish.

bursan $<$ Sogd. pwrsnk(') < Chin. 佛僧 fo sēng. religious community.

If considered by frequency, it is understood that word bursay is a borrowed word. It is possible to see this word in almost every writing of the Old Uighur era. It would be fair to say that bursay had a place for itself in the language. The word carried the meaning of "religious community, Buddhist group..." (G. 3589, 9617) but the more frequently used one was "religious community". The word was used in this conceptual field in Old Uighur and found itself a large area of use with reference to "religious community". If we pay attention to the phonological features of the word, it could be understood that it was borrowed through $<\operatorname{Sogd}$. pwrsnk( $\left(^{\circ}\right) /$ pursang. < Sogd. pursang < *Skr. bhikșu-samgha "monk' community of monks" (Gharib: $331 \mathrm{a}_{8218}$ ). It was also used with the word kuvrag and made a reduplication. It almost has the same conceptual field as the word kuvrag together with which it made a reduplication. The word kuvrag could, both single-handedly or in reduplication with bursay or yükmek (Şen 2002: 77; 180), bear the meaning "community; religious community". All this information strengthens the idea of the word being a prestige borrowing rather than a need borrowing.

çın $<$ Chin. 県 zhèn. real, truth.

If considered by frequency, it is understood that the word çın is a borrowed word. It is possible to see this word in almost every writing in the Old Uighur language. It could be said that the word çın found a place for itself in the language. It is used with the meaning "real, truth" in both Chinese and Old Uighur. It could be seen that it is borrowed from Chinese with its morphological and semantic structures. It is seen that it performs a reduplication, and sometimes a triplication, with kirtü, köni, tüz. It almost has the same conceptual field with its triplication and reduplication words. Thus, it could be said that the word was borrowed for reasons of prestige.

sü/süö $<$ Chin. 序 $x u$. foreword.

This word is a borrowing. It was particularly used in substitution for the terms "foreword, introduction", in the context of book chapters. It is also used in that conceptual field in some sentences, for example: tükedi kimkoki atl(l)g nom erdini içinteki tört altmış bölük takşutlug şloklarnıり törümiş tıltagı sü̈̈ yörügi:...: (Hazai-Zieme 1971: $20_{39-41}$ ). The word was used with 
the meanings “order; alignment, chapter, introduction" (G. 4771) in Chinese. It could be seen that it is borrowed with its Chinese phonological, morphological and semantic structures. The only replacement we could think of for the borrowed term is başdınkı but it has a different area of use and is mostly used to describe the first chapter of books, in the context of book chapters. This situation makes us think that the word is borrowed as a term with intention to fulfil a need.

\section{Conclusion}

One of the most frequently encountered products of language contact is borrowings that follow intercultural communication. The study of borrowings in a language involves many linguistics aspects. The main result of languages having contact with each other is the acquisition of loanwords. Many scholars have conducted much study and reached similar results in this area. Historical linguists study borrowed words to compare languages and to understand how and why languages change. The study of loanwords, and of language contact more generally, is a useful way to trace linguistic change in the past. Because borrowings are very important in Historical Linguistics studies, we studied Chinese borrowings in the Old Uigur era writings in this study. We tried to show Chinese borrowings in the Old Uigur era and the reasons why these words were borrowed. Determining the reasons for borrowing words in the Old Uigur era, given the great volume of books which have been written in Old Turkish, is the priority of this study. In addition to this, original and new language notes that are summarized from the documents where the borrowings are seen, make this study even more important. In this study, Chinese borrowings in the mentioned era were investigated with historical linguistics methods and the results were presented to scholars of Turkish Language or linguistics. In this way, we hope to contribute something new to Linguistics and Turcology. In this study, we investigated how Old Uighurs borrowed from foreign languages and whether the borrowings were prestige, reverse prestige or needed borrowings along with other reasons.

This sample study on Chinese borrowings in Old Uighur texts and their borrowing process, will pave the way for future studies. This study sets the ground for further studies on both Chinese borrowings in Old Uighur and borrowings from other languages. In the light of the difficulties we faced in this study, we approached it more systematically. Borrowings were evaluated with the comparative method and the linguistic reconstruction method under the topics "phonological leads", "morphological complexity", "leads from cognate structures", "geographic and ecological leads", "semantic values". Furthermore, we tried to conclude the reasons and manners of borrowings. 
Peer-review: Externally peer-reviewed.

Conflict of Interest: The author has no conflict of interest to declare.

Grant Support: This study is supported by project number 25096 of BAP (Office of Scientific Research Project) at Universty of Istanbul.

Hakem Değerlendirmesi: Dış bağımsız.

Çıkar Çatışması: Yazar çıkar çatışması bildirmemiştir.

Finansal Destek: Bu çalışma İstanbul Üniversitesi tarafından 25096 nolu Bilimsel Araştırma Projesi olarak desteklenmiştir.

\section{References/Kaynakça}

Adams, D. Q. (2013). Dictionary of Tocharian B., Amsterdam-New York, Rodopi.

Aksan, D. (2009). Her Yönüyle Dil, Ana Çizgileriyle Dil Bilim 1. 2. 3. volumes (5. edition). Ankara, TDK Press.

Atalay, B. (1985). Divanü Lûgat-it-Türk Tercümesi I-II-III-IV., Ankara. TDK Press.

Aydemir, H. (2013). Die alttürkische Xuanzang-Biographie IX Nach der Handschrift von Paris, Peking und

St. Petersburg sowie nach dem Transkript von Annemarie v. Gabain ediert, überstzt und kommentiert I-II,

Göttingen, Harrassowitz Verlag.

Bloomfield, L. (1933). Language, (Reprinted 1973), London, George Allen and Unwin ltd.

Campbell L. (1999). Historical Linguistics An Introduction. Cambridge, Massachusetts, The MIT Press.

Clauson, S. G. (1972). An Etymological Dictionary of Pre-Thirteenth- Century Turkish, Oxford, Clarendon Press.

Csongor, B. (1952). "Chinese in the Uighur of the T'ang-Period", Acta Orientalia Academiae scientiarum Hungaricae, 2, pp. 73-121.

--- (1954). "Some more Chinese Gloesses in Uighur Script", Acta Orientalia Academiae scientiarum Hungaricae, 4, pp. 251-257

Çetin, E. (2013). Altun Yaruk Yedinci Kitap Berlin Bilimler Akademisindeki Metin Parçaları Karşılaştırmalı Metin, Çeviri, Açılkamalar, Dizin, Adana, Karahan Press.

De Saussure, F. (1915). A course in general linguistics. C. Bally and A. Sechehaye (eds.) Wade Baskin, trans. New York: McGraw-Hill. 1959.

Doğan, Ş. (2009). "On Intimate Borrowings in Old Uighur Turkish Translations Text", Sakarya Universty Faculty of Science and Letters, IX. International Language-Literature-Stylistics Symposium's Papers Book, Vol. I, p. 326-344.

Durmuş, O. (2004). “Alıntı Kelimeler Bakımından Türkçe Sözlük”, A.Ü. Türkiyat Araştırmaları Enstitüsü Dergisi, volume 26, Erzurum, pp. 1-21.

Elmalı, M. (2016). Daśakarmapathaavadānamālā, Ankara, TDK Press.

Gharib, B. (1995). Sogdian Dictionary (Sogdian-Persian-English), Tehran, Farhangan Press.

Giles, H. (1912). A Chinese- English Dictionary, Shangai-London.

Hazai, G. - Zieme, P. (1972). Fragmente der uigurischen Version des “Jin'gangjing mit den Gathas des Meister $F u$ ", Berliner Turfan Text I, Berlin, Akademie Verlag.

Hoffer B. L. (2002). "Language Borrowing and Language Diffusion: An Overview”, Intercultural Communication Studies XI: 4, p. 1-37.

İşihara, A. (2005). Yazı Dilindeki Alıntı Kelimelerin Türkçeleşme Süreçleri, Universty of İstanbul Institute of 
Social Sciences Unpublished Master Thesis, İstanbul.

İşiwata, T. (2001). Gairaigo No Soogooteki Kenkyuu. Tokyo, Tokyodoo Press.

Jeffers, J. R.-Lehiste, I. (1982). Principles and Methods for Historical Linguistics. Cambridge, MIT Press.

Karaağaç, G. (2008). Dil Tarih ve İnsan. İstanbul, Kitabevi Press.

Ölmez, M. (1994). "Uygurca Xuanzang-Biyograsindeki Çince Alıntılar. (Chinesische Lehnwörter in uigurischer Xuanzan-Biographie)" TDA 4, pp. 109-143.

Ölmez, M. (2007). Tuwinischer Wortschatz, mit alttükischen und mongolischen Parallelen = Tuvacanın Sözvarlı̆̆l: Eski Türkçe ve Moğolca Denkleriyle. Wiesbaden, Harrassowitz Verlag.

Paylan, K (2015). Türkçede Kelime Türetme Yollarına Genel Bir Bakış, Universty of Pamukkale Institute of Education Sciences, Unpublished Master Thesis, Denizli.

Ricquer, B. (2018). "Historical Linguistics: Loanwords and Borrowing" Oxford Research Encyclopedia of African History, (oxfordre.com/africanhistory). (c) Oxford University Press USA.

Röhrborn, K. (1991). Die alttürkische Xuanzang-Biographie VII, Nach der Handschrift von Leningrad, Paris und Peking sowei nach dem Transkript von Annemarie v. Gabain, Otto Harrassowitz, Wiesbaden.

Salan, M. (2012). “Kitabü'l-İdrak Li Lisani'l-Etrak’te Alıntı Kelimeler”, Gazi Türkiyat. Autumn 2012/11, pp. 53-66.

Sapir E. (1921). Language. New York: Harcourt, Brace \& World.

Sertkaya, O. F. (1978). "Uygur metinlerinde yanlış, okuma ve anlamalar (1. Müstensih "Tökülti” üzerine notlar)". Türk Kültürü, XVI/189, 1978, pp. 572-574.

Shogaito, M. (1986). “Chinese Loanwords in Uighur” Studies on the Inner Asian Language II, pp. 124-156 Soothill, W. E. - Hodous, L. (1975). A Dictionary of Chinese Buddhist Terms, Taipei. Motilal Banarsidass.

Şen, S. (2002). Eski Uygur Türkçesinde İkilemeler. Universty of Ondokuz Mayıs Institute of Social Sciences, Unpublished Master Thesis, Samsun.

Thomason, Sarah G. (2001). Language Contact, Edinburgh, Edinburgh University Press.

Tokyürek, H. (2018). "Classification of Chinese Words in The Xuanzang Biography”, Dil Araştırmaları, Autumun, 23, p. 123-157.

Tekin, Ş. (1976). Maytrısimit-Burkancılı̆̆ın Mehdisi Maitreya ile Buluşma Uygurca Íptidai Bir Dram. Ankara. 
